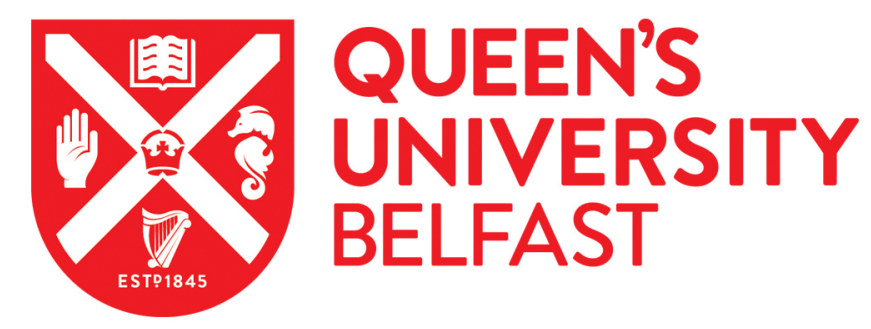

\title{
Effects of arbuscular mycorrhizal fungi and ammonium:nitrate ratios on growth and pungency of onion seedlings
}

Guo, T., Zhang, J. L., Christie, P., \& Li, X. L. (2006). Effects of arbuscular mycorrhizal fungi and ammonium:nitrate ratios on growth and pungency of onion seedlings. Journal of Plant Nutrition, 29(6), 10471059. https://doi.org/10.1080/01904160600689175

Published in:

Journal of Plant Nutrition

Queen's University Belfast - Research Portal:

Link to publication record in Queen's University Belfast Research Portal

\section{General rights}

Copyright for the publications made accessible via the Queen's University Belfast Research Portal is retained by the author(s) and / or other copyright owners and it is a condition of accessing these publications that users recognise and abide by the legal requirements associated with these rights.

Take down policy

The Research Portal is Queen's institutional repository that provides access to Queen's research output. Every effort has been made to ensure that content in the Research Portal does not infringe any person's rights, or applicable UK laws. If you discover content in the Research Portal that you believe breaches copyright or violates any law, please contact openaccess@qub.ac.uk. 


\title{
Effects of Arbuscular Mycorrhizal Fungi and Ammonium: Nitrate Ratios on Growth and Pungency of Onion Seedlings
}

\author{
Tao Guo, ${ }^{1}$ Junling Zhang, ${ }^{1}$ Peter Christie, ${ }^{1,2}$ and Xiaolin $\mathrm{Li}^{1}$ \\ ${ }^{1}$ College of Resources and Environmental Sciences, China Agricultural University, \\ Key Laboratory of Plant-Soil Interactions, Ministry of Education, and Key Laboratory \\ of Plant Nutrition, Ministry of Agriculture, Beijing, China \\ ${ }^{2}$ Agricultural and Environmental Science Department, Queen's University Belfast, \\ Belfast, UK
}

\begin{abstract}
A pot experiment was conducted to study the growth and pungency of Allium cepa L. grown in Perlite as affected by colonization by the arbuscular mycorrhizal (AM) fungi Glomus versiforme and Glomus intraradices BEG141 and by ammonium:nitrate $\left(\mathrm{NH}_{4}^{+}: \mathrm{NO}_{3}^{-}\right)$ratios of $3: 1,1: 1$, and 1:3 in $4 \mathrm{~m} M$ solutions. Plants were harvested when bulb formation commenced. In general, mycorrhizal colonization resulted in increased shoot dry weight, shoot length, sheath diameter, root nitrogen $(\mathrm{N})$ and phosphorus $(\mathrm{P})$ content (except with $G$. intraradices and a $\mathrm{NH}_{4}^{+}: \mathrm{NO}_{3}^{-}$ratio of $1: 3$ ), shoot $\mathrm{N}$ and $\mathrm{P}$ concentrations (except with G. versiforme and a $\mathrm{NH}_{4}^{+}: \mathrm{NO}_{3}{ }^{-}$ratio of 3:1) and content. Plants inoculated with $G$. versiforme had higher growth parameters and $\mathrm{N}$ and $\mathrm{P}$ content than those with $G$. intraradices, whereas $\mathrm{N}$ and $\mathrm{P}$ concentrations showed the opposite trends. Growth parameters and $\mathrm{N}$ and $\mathrm{P}$ content of non-mycorrhizal plants were highest at a $\mathrm{NH}_{4}^{+}: \mathrm{NO}_{3}{ }^{-}$ratio of $1: 3$, while those of plants inoculated with $G$. versiforme or G. intraradices were highest at a ratio of $\mathrm{NH}_{4}^{+}: \mathrm{NO}_{3}^{-} 3: 1$ or $1: 1$. Neither mycorrhizal colonization nor proportion of inorganic $\mathrm{N}$ species significantly affected bulb enzyme-produced pyruvate or total or organic sulfur $(S)$ concentrations in plant shoots. Colonization by AM fungi made a substantial contribution to onion growth and may not have been directly related to bulb pungency at early stages of plant growth. However, the influence of $\mathrm{AM}$ fungi on plant $\mathrm{N}$ and $\mathrm{P}$ metabolism may have implications for onion flavor at later stages of plant growth.
\end{abstract}

Received 10 March 2005; accepted 9 September 2005.

Address correspondence to Junling Zhang, College of Resources and Environmental Sciences, China Agricultural University, Beijing 100094, P. R. China. E-mail: junlingz@cau.edu.cn 
Keywords: plant growth, enzyme-produced pyruvate, ammonium: nitrate ratios, arbuscular mycorrhiza, onion

\section{INTRODUCTION}

Onion (Allium Cepa L.) and other Allium species produce aroma and flavor compounds that are recognized as having potential benefit for human health (Amagase et al., 2001). The flavor arises as the flavor precursors, S-alk(en)yl cysteine sulfoxides (ACSO), are enzymatically decomposed.

Nitrogen $(\mathrm{N})$ is a major element required for plant growth and has been shown to affect the growth, maturity, yield, flavor, and bulb quality of onion (Randle, 2000; Coolong et al., 2004). In addition, the form of $\mathrm{N}$ supplied influences onion growth and bulb quality but the mechanism by which bulb pungency is affected remains unknown (Gamiely et al., 1991). The quantity and form of $\mathrm{N}$ supplied may therefore need to be considered when growing onions for specific flavor intensity and quality attributes.

The contribution of mycorrhizal colonization to plant growth and nutrient uptake [particularly those such as phosphorus (P), zinc ( $\mathrm{Zn})$, and copper $(\mathrm{Cu})$, which are less mobile in the soil], as well as to disease control, drought resistance, and plant performance in adverse soil conditions, has been widely documented in the literature (Smith and Read, 1997). Recent work indicates that AM inoculation can enhance oil quality in fennel (Foeniculum vulgare Mill.) (Kapoor et al., 2004). It is generally known that onion and other Allium species can be highly dependent on AM colonization for normal growth in soils and that plants are often severely stunted if they are not mycorrhizal (Charron et al., 2001). However, no attempt has been made to investigate the effect of AM fungi on onion flavor, and most experiments relevant to onion flavor (Randle et al., 1998; Randle, 2000; Coolong et al., 2004) have been conducted under conditions in which mycorrhizal symbiosis has not been considered.

The aim of the present experiment was to investigate the effect of inorganic $\mathrm{N}$ form $\left(\mathrm{NH}_{4}^{+}\right.$vs. $\left.\mathrm{NO}_{3}^{-}\right)$and $\mathrm{AM}$ colonization on the growth and pungency of onion. Previous research has shown that onion growth and bulb pungency at maturity were higher when $\mathrm{NO}_{3}^{-}$was present compared with $\mathrm{NH}_{4}^{+}$as the sole form of $\mathrm{N}$ supply in the substrate (Gamiely et al., 1991). Plants were harvested when small bulbs emerged in order to observe the effect of different proportions of $\mathrm{NH}_{4}^{+}$and $\mathrm{NO}_{3}^{-}$and $\mathrm{AM}$ colonization on onion growth and bulb pungency at early stages of plant growth. Three $\mathrm{NH}_{4}^{+}: \mathrm{NO}_{3}^{-}$ratios $(3: 1,1: 1$, and 1:3) were used to study situations in which each inorganic species was the dominant form of $\mathrm{N}$ present and when they were present in equal quantities in the substrate. 


\section{MATERIALS AND METHODS}

Perlite (1-3 mm) was washed over $1 \mathrm{~mm}$ mesh under tap water to remove the fine powder, then sun-dried and heated in an oven at $110^{\circ} \mathrm{C}$ for $24 \mathrm{~h}$ before use. Aliquots of the Perlite $\left(600 \mathrm{~cm}^{3}\right)$ were then placed in round plastic pots $(1 \mathrm{~L}$, $14 \mathrm{~cm}$ in diameter). First, about $150 \mathrm{~cm}^{3}$ of Perlite was placed in the bottom of each pot, followed by $300 \mathrm{~cm}^{3}$ of Perlite mixed thoroughly with mycorrhizal inoculum, and the remainder of the Perlite was then placed on top. Mycorrhizal treatments received $60 \mathrm{~g}$ AM inoculum and non-mycorrhizal controls received an equivalent amount of sterilized inoculum together with a filtrate $(0.45 \mu \mathrm{m}$ pore size) of unsterilized soil to provide for similar microflora except for the absence of the AM fungus. The inoculum consisted of loose soil from pot cultures containing spores and maize (Zea Mays L.) root pieces colonized by Glomus versiforme or Glomus intraradices BEG 141.

Seeds of onion (Allium cepa L.) were surface sterilized in a $10 \%(\mathrm{v} / \mathrm{v})$ solution of hydrogen peroxide for $10 \mathrm{~min}$, then sown in sterilized turf and irrigated with deionized water. One seedling was transplanted into each pot at the fifth-leaf stage. A thin layer of sterilized sand was placed on the surface of the substrate to reduce evaporation. The seedlings all grew in water with $1 / 10$ fullstrength nutrient solution for the first week and thereafter in solution with the different experimental treatments. The nutrient solution followed Hawkins and George (1999) except for $\mathrm{N}$, with the following composition: $\mathrm{NaH}_{2} \mathrm{PO}_{4}, 0.094$ $\mathrm{mM} ; \mathrm{Na}_{2} \mathrm{HPO}_{4}, 0.006 \mathrm{mM} ; \mathrm{K}_{2} \mathrm{SO}_{4}, 1 \mathrm{mM} ; \mathrm{CaCl}_{2}, 2 \mathrm{mM} ; \mathrm{MgSO}_{4}, 0.75 \mathrm{mM}$; $\mathrm{H}_{3} \mathrm{BO}_{3}, 69 \mu \mathrm{M} ; \mathrm{CuSO}_{4}, 1.7 \mu \mathrm{M} ; \mathrm{ZnSO}_{4}, 1.2 \mu \mathrm{M} ; \mathrm{MnSO}_{4}, 10.4 \mu \mathrm{M} ; \mathrm{NaMoO}_{4}$, $0.13 \mu \mathrm{M}$; and Fe-EDTA, $0.3 \mu \mathrm{M}$. Nitrogen (4 mM) was supplied as $\mathrm{NH}_{4} \mathrm{Cl}$ and $\mathrm{Ca}\left(\mathrm{NO}_{3}\right)_{2}$ to obtain three ratios of $\mathrm{NH}_{4}^{+}-\mathrm{N}$ and $\mathrm{NO}_{3}^{-}-\mathrm{N}(1: 3,1: 1$, and $3: 1)$, the $\mathrm{pH}$ of the nutrient solution was adjusted to $\mathrm{pH}$ 6.0, and MES buffer was added. Seedlings were watered once every $3 \mathrm{~d}$ with the nutrient solution. The Perlite was washed thoroughly once a week to minimize accumulation of the salts. Plants were grown for five months in a culture room with day/night temperature of $26^{\circ} \mathrm{C}-30^{\circ} \mathrm{C}$, relative humidity of $30 \%-40 \%$, and an average photosynthetic photon-flux density of 230-280 $\mu \mathrm{E} \mathrm{m}^{-2} \mathrm{~s}^{-1}$ provided by reflector sunlight dysprosium lamps (DDF 400, Nanjing, China) for $14 \mathrm{~h}$ each day. There were four replicates, giving a total of 36 pots arranged in randomized blocks.

Plants were harvested when bulb formation commenced and plants were separated into bulb, shoots, and roots. Root samples ( $0.5 \mathrm{~g}$ fresh weight) were cut into $1 \mathrm{~cm}$ long segments to determine the proportion of root length colonized by AM fungi as described by Giovannetti and Mosse (1980). Pungency as an indicator of onion flavor was measured by the pyruvic acid method (Randle, 1992; Randle et al., 1995), i.e., enzyme-produced pyruvate (EPY). The higher the EPY, the more pungent the onion. Briefly, the reaction of 2, 4-dinitro phenylhydrazine (DNPH) with $\mathrm{NaOH}$ was used to detect the presence of pyruvic acid (enzymatically formed pyruvate). A sample of shoot tissue (5 g fresh 
weight) was blended with equal volumes of water for 3-5 min. Equal aliquots of trichloroacetic acid and onion slurry were combined after $20 \mathrm{~min}$, incubated for $1 \mathrm{~h}$, and then filtered through cheese cloth. One $\mathrm{ml}$ of the filtrate was added to $1 \mathrm{ml} 0.0125 \%$ 2, 4-dinitro-phenyl-hydrazine in $2 \mathrm{M} \mathrm{HCl}$ plus $1 \mathrm{~mL}$ water and incubated at $37^{\circ} \mathrm{C}$ for $10 \mathrm{~min}$. Five $\mathrm{ml} \mathrm{NaOH}$ were then added before the absorbance was read at $420 \mathrm{~nm}$ on a spectrophotometer. Pyruvate determinations were made against a sodium pyruvate standard curve.

The remainder of the plant material was dried in an air-forced oven at $70^{\circ} \mathrm{C}$ for $48 \mathrm{~h}$ and weighed. Oven-dried samples were milled with a high-speed multi-function micro-pulverizer (Whirl Type Model Y-60, Hebei, China) prior to elemental analysis. For the measurement of $\mathrm{P}$ and $\mathrm{N}$ concentrations, subsamples (about $0.3 \mathrm{~g}$ ) were wet digested on a block digester (Kjeldatherm, Gerhardt $\mathrm{GmbH}$, Germany) with $\mathrm{H}_{2} \mathrm{SO}_{4}$ and $\mathrm{H}_{2} \mathrm{O}_{2}$. Plant $\mathrm{N}$ concentration was determined using a micro-Kjeldahl method (Hendershot, 1985) and P concentration was determined by the vanado-molybdate method (Colwell, 1965) using a Shimadzu Model UV-120-02 spectrophotometer.

Total S concentration was determined as described by Gaines and Mitchell (1979). Briefly, plant tissue was dried at $70^{\circ} \mathrm{C}$ for $72 \mathrm{~h}$ in a forced-air oven and then ground to pass through a $0.5 \mathrm{~mm}$ screen. Total sulfur $(\mathrm{S})$ was oxidized to $\mathrm{SO}_{4}^{2-}$ by heating the dried tissue with $\mathrm{Mg}\left(\mathrm{NO}_{3}\right)_{2} \cdot 6 \mathrm{H}_{2} \mathrm{O}$. The samples were then ashed in a muffle furnace. Sulfate was extracted by dissolving the ash in hot diluted $\mathrm{HCl}$. The dissolved $\mathrm{SO}_{4}^{2-}$ was precipitated with barium chloride and percent total $\mathrm{S}$ was determined turbidimetrically with a spectrophotometer at $420 \mathrm{~nm}$ against a $\mathrm{CaSO}_{4} \cdot 2 \mathrm{H}_{2} \mathrm{O}$ standard curve. Plant tissue $\mathrm{SO}_{4}^{2-}$ was determined following the same method, but without the addition of the $\mathrm{Mg}\left(\mathrm{NO}_{3}\right)_{2} \cdot 6 \mathrm{H}_{2} \mathrm{O}$ prior to ashing.

Two-way analysis of variance with replication was performed using the SAS statistical software package (Version 6.12; SAS Institute, Cary, NC).

\section{RESULTS}

No AM colonization was observed on the roots of uninoculated control plants (Table 1). There was no significant difference between $G$. versiforme and $G$. intraradices in their rates of root colonization of inoculated plants regardless of $\mathrm{NH}_{4}^{+}: \mathrm{NO}_{3}^{-}$ratio, except that plants inoculated with $G$. versiforme (with a ratio of $3: 1$ ) had a much lower colonization rate than those inoculated with G. intraradices (with a ratio of 1:1). In general the shoot and root dry weights of onion seedlings inoculated with $G$. versiforme or $G$. intraradices were significantly higher than those of the non-mycorrhizal controls in all $\mathrm{NH}_{4}^{+}: \mathrm{NO}_{3}^{-}$ ratios (except the root dry weight of $G$. intraradices at a ratio of 1:3). Plants inoculated with $G$. versiforme had higher shoot and root dry weights than those with $G$. intraradices. The highest shoot and root dry weights were found with the $\mathrm{NH}_{4}^{+}: \mathrm{NO}_{3}^{-}$ratio of 1:3 in non-mycorrhizal, 3:1 in G. versiforme and 1:1 in G. intraradices inoculated plants, respectively. Similar trends were observed 
Table 1

Mean shoot dry weight, root dry weight, shoot-to-root ratio, shoot length, sheath diameter, and colonization rate of onion plants

\begin{tabular}{|c|c|c|c|c|c|c|}
\hline $\begin{array}{l}\mathrm{N} \text { form ratio and } \\
\text { mycorrhizal status }\end{array}$ & $\begin{array}{l}\text { Shoot } \\
(\mathrm{g})\end{array}$ & $\begin{array}{c}\text { Root } \\
(\mathrm{g})\end{array}$ & $\begin{array}{l}\text { Shoot:root } \\
\text { ratio }\end{array}$ & $\begin{array}{l}\text { Shoot } \\
\text { length } \\
(\mathrm{mm})\end{array}$ & $\begin{array}{l}\text { Sheath } \\
\text { diameter } \\
(\mathrm{mm})\end{array}$ & $\begin{array}{c}\text { Colonization } \\
\text { rate } \\
(\%)\end{array}$ \\
\hline \multicolumn{7}{|l|}{$\mathrm{NH}_{4}^{+}: \mathrm{NO}_{3}^{-} 3: 1$} \\
\hline Non-mycorrhizal & 1.21 & 0.16 & 7.3 & 115 & 6.2 & ND \\
\hline G. intraradices & 1.82 & 0.18 & 10.3 & 121 & 8.3 & 43 \\
\hline G. versiforme & 3.65 & 0.32 & 11.3 & 144 & 10.8 & 42 \\
\hline \multicolumn{7}{|l|}{$\mathrm{NH}_{4}^{+}: \mathrm{NO}_{3}^{-} 1: 1$} \\
\hline Non-mycorrhizal & 1.45 & 0.17 & 8.9 & 117 & 6.6 & $\mathrm{ND}^{b}$ \\
\hline G. intraradices & 2.93 & 0.22 & 13.8 & 130 & 10.0 & 54 \\
\hline G. versiforme & 3.21 & 0.28 & 11.8 & 142 & 11.0 & 48 \\
\hline \multicolumn{7}{|l|}{$\mathrm{NH}_{4}^{+}: \mathrm{NO}_{3}^{-} 1: 3$} \\
\hline Non-mycorrhizal & 2.13 & 0.27 & 7.8 & 114 & 8.3 & ND \\
\hline G. intraradices & 2.24 & 0.15 & 15.4 & 119 & 8.7 & 46 \\
\hline G. versiforme & 2.83 & 0.31 & 9.3 & 135 & 9.4 & 50 \\
\hline \multicolumn{7}{|l|}{ Significance $^{a}$ due to: } \\
\hline $\begin{array}{c}\text { Inoculation } \\
\text { treatment }\end{array}$ & *** & $* * *$ & $* * *$ & $* * *$ & $* * *$ & NS \\
\hline $\mathrm{N}$ form ratio & NS & NS & NS & NS & NS & NS \\
\hline $\begin{array}{l}\text { Inoculation } \times \mathrm{N} \\
\text { form ratio }\end{array}$ & $* * *$ & $* * *$ & NS & NS & $*$ & NS \\
\hline
\end{tabular}

${ }^{a}$ By analysis of variance; ${ }^{* * *}, \mathrm{P}<0.001 ;{ }^{*}, \mathrm{P}<0.05$; NS, not significant.

${ }^{b} \mathrm{ND}$, not determined: no colonization observed on roots of uninoculated controls.

for shoot length, sheath diameter, and shoot/root ratio between non-mycorrhizal and mycorrhizal plants. The effect of mycorrhizal colonization was significant but $\mathrm{N}$ species ratio was not.

Nitrogen concentrations in the shoots of plants inoculated with $G$. intraradices were higher than in the non-mycorrhizal controls at all three $\mathrm{N}$ molar ratios, and significant differences were observed at $\mathrm{NH}_{4}^{+}: \mathrm{NO}_{3}^{-}$ratios of $1: 1$ and 1:3 (Table 2). Plants inoculated with $G$. versiforme had significantly higher shoot $\mathrm{N}$ concentration than the non-mycorrhizal control only at a $\mathrm{NH}_{4}^{+}: \mathrm{NO}_{3}^{-}$ ratio of $1: 1$, while at a $\mathrm{NH}_{4}^{+}: \mathrm{NO}_{3}^{-}$ratio of $3: 1, \mathrm{~N}$ concentration was significantly lower than in the non-mycorrhizal plants. Non-mycorrhizal plants and plants inoculated with $G$. intraradices had the highest $\mathrm{N}$ concentrations at a $\mathrm{NH}_{4}^{+}: \mathrm{NO}_{3}^{-}$ ratio of 3:1, while plants inoculated with $G$. versiforme had the highest at a ratio of $1: 1$. There was no significant difference in root $\mathrm{N}$ concentration regardless of mycorrhizal colonization or $\mathrm{N}$ molar ratio.

Mycorrhizal colonization resulted in increased $\mathrm{N}$ content in plant shoots regardless of the $\mathrm{N}$ molar ratio (Table 2). There was a tendency for plants inoculated with $G$. versiforme to have higher shoot $\mathrm{N}$ content than those inoculated 
Table 2

Nitrogen concentration and $\mathrm{N}$ content of onion plants

\begin{tabular}{|c|c|c|c|c|}
\hline \multirow[b]{2}{*}{$\mathrm{N}$ ratio and mycorrhizal status } & \multicolumn{2}{|c|}{$\mathrm{N}$ concentration $(\%)$} & \multicolumn{2}{|c|}{$\mathrm{N}$ content $(\mathrm{mg})$} \\
\hline & Shoot & Root & Shoot & Root \\
\hline \multicolumn{5}{|l|}{$\mathrm{NH}_{4}^{+}: \mathrm{NO}_{3}^{-} 3: 1$} \\
\hline Non-mycorrhizal & 1.52 & 1.07 & 17.96 & 1.67 \\
\hline G. intraradices & 1.63 & 0.96 & 29.78 & 1.73 \\
\hline G. versiforme & 1.17 & 1.04 & 42.52 & 3.39 \\
\hline \multicolumn{5}{|l|}{$\mathrm{NH}_{4}^{+}: \mathrm{NO}_{3}^{-} 1: 1$} \\
\hline Non-mycorrhizal & 1.19 & 0.92 & 17.30 & 1.53 \\
\hline G. intraradices & 1.41 & 1.04 & 41.30 & 2.20 \\
\hline G. versiforme & 1.39 & 1.13 & 44.43 & 3.11 \\
\hline \multicolumn{5}{|l|}{$\mathrm{NH}_{4}^{+}: \mathrm{NO}_{3}^{-} 1: 3$} \\
\hline Non-mycorrhizal & 1.22 & 0.98 & 25.99 & 2.71 \\
\hline G. intraradices & 1.46 & 0.95 & 32.55 & 1.38 \\
\hline G. versiforme & 1.27 & 1.05 & 36.02 & 3.18 \\
\hline \multicolumn{5}{|l|}{ Significance $^{a}$ due to: } \\
\hline Inoculation treatment & $* * *$ & NS & $* * *$ & $* * *$ \\
\hline $\mathrm{N}$ form ratio & NS & NS & NS & NS \\
\hline Inoculation $\times \mathrm{N}$ form ratio & $* * *$ & NS & $* *$ & $* *$ \\
\hline
\end{tabular}

${ }^{a}$ By analysis of variance; ${ }^{* * *}, \mathrm{P}<0.001 ;{ }^{* *}, \mathrm{P}<0.01$; NS, not significant.

with $G$. intraradices, and significant differences between plants inoculated with the two fungi were observed at a $\mathrm{NH}_{4}^{+}: \mathrm{NO}_{3}^{-}$ratio of $3: 1$. The non-mycorrhizal plants had the highest shoot- $\mathrm{N}$ content at an $\mathrm{NH}_{4}^{+}: \mathrm{NO}_{3}^{-}$ratio of 1:3, while plants inoculated with the two fungi had the highest shoot $\mathrm{N}$ content at a $\mathrm{NH}_{4}^{+}: \mathrm{NO}_{3}^{-}$ ratio of 1:1. The shoot $\mathrm{N}$ content of non-mycorrhizal plants and inoculated plants did not differ significantly between the other two $\mathrm{N}$ molar ratios. Root N content of $G$. versiforme inoculated plants was significantly higher than that of the non-mycorrhizal control, while that of $G$. intraradices inoculated plants was significantly higher (at a $\mathrm{NH}_{4}^{+}: \mathrm{NO}_{3}^{-}$ratio of $1: 1$ or $3: 1$ ) or lower ( $\mathrm{N}$ molar ratio of 1:3) than that of the controls. A similar tendency was observed for $\mathrm{P}$ concentration and $\mathrm{P}$ content (Table 3 ) in plants not inoculated or inoculated with the two fungi.

There was no significant effect of mycorrhizal colonization or $\mathrm{N}$ molar ratio on bulb EPY (Table 4). However, mycorrhzal colonization resulted in higher bulb EPY at a $\mathrm{NH}_{4}^{+}: \mathrm{NO}_{3}^{-}$ratio of $1: 1$. While bulb EPY value in plants inoculated with $G$. intraradices was comparable to ( $\mathrm{N}$ molar ratio of 1:3) or higher than ( $\mathrm{N}$ molar ratio of 3:1) that in the non-mycorrhizal plants, plants inoculated with $G$. versiforme had lower bulb EPY than the non-mycorrhizal plants at these two $\mathrm{N}$ molar ratios. 
Table 3

Phosphorus concentration and $\mathrm{P}$ content of onion plants

\begin{tabular}{|c|c|c|c|c|}
\hline \multirow[b]{2}{*}{$\mathrm{N}$ ratio and mycorrhizal status } & \multicolumn{2}{|c|}{$\mathrm{P}$ concentration $(\%)$} & \multicolumn{2}{|c|}{$\mathrm{P}$ content $(\mathrm{mg})$} \\
\hline & Shoot & Root & Shoot & Root \\
\hline \multicolumn{5}{|l|}{$\mathrm{NH}_{4}^{+}: \mathrm{NO}_{3}^{-} 3: 1$} \\
\hline Non-mycorrhizal & 0.20 & 0.24 & 2.43 & 0.37 \\
\hline G. intraradices & 0.27 & 0.32 & 4.93 & 0.56 \\
\hline G. versiforme & 0.18 & 0.20 & 6.38 & 0.64 \\
\hline \multicolumn{5}{|l|}{$\mathrm{NH}_{4}^{+}: \mathrm{NO}_{3}^{-} 1: 1$} \\
\hline Non-mycorrhizal & 0.17 & 0.14 & 2.48 & 0.23 \\
\hline G. intraradices & 0.21 & 0.22 & 5.94 & 0.47 \\
\hline G. versiforme & 0.22 & 0.23 & 7.06 & 0.62 \\
\hline \multicolumn{5}{|l|}{$\mathrm{NH}_{4}^{+}: \mathrm{NO}_{3}^{-} 1: 3$} \\
\hline Non-mycorrhizal & 0.16 & 0.15 & 3.36 & 0.41 \\
\hline G. intraradices & 0.26 & 0.21 & 5.53 & 0.30 \\
\hline G. versiforme & 0.21 & 0.23 & 5.79 & 0.71 \\
\hline \multicolumn{5}{|l|}{ Significance $^{a}$ due to: } \\
\hline Inoculation treatment & $* * *$ & NS & $* * *$ & $* * *$ \\
\hline $\mathrm{N}$ form ratio & NS & NS & NS & NS \\
\hline Inoculation $\times \mathrm{N}$ form ratio & $* *$ & NS & NS & NS \\
\hline
\end{tabular}

${ }^{a}$ By analysis of variance; ***, $\mathrm{P}<0.001 ;{ }^{* *}, \mathrm{P}<0.01 ;{ }^{*}, \mathrm{NS}$, not significant.

Total sulfur concentration (TSC) in the plant shoots was not significantly affected by $\mathrm{N}$ molar ratio (Table 4). Plants inoculated with $G$. intraradices had increased TSC at a $\mathrm{NH}_{4}^{+}: \mathrm{NO}_{3}^{-}$ratio of $3: 1$ or $1: 3$, while TSC in inoculated plants at the $\mathrm{NH}_{4}^{+}: \mathrm{NO}_{3}^{-}$ratio 1:1 was comparable to that in the controls. In contrast, plants inoculated with $G$. versiforme had lower TSC than the controls at $\mathrm{NH}_{4}^{+}: \mathrm{NO}_{3}^{-}$ratios of $1: 1$ and $3: 1$, while at a $\mathrm{NH}_{4}^{+}: \mathrm{NO}_{3}^{-}$ratio of $1: 3$, TSC in inoculated plants was comparable to that in the controls. Organic sulfur concentration (OSC) in plant shoots as affected by $\mathrm{N}$ molar ratio and mycorrhizal colonization followed trends similar to TSC in the shoots of non-mycorrhizal and mycorrhizal plants.

\section{DISCUSSION}

The presence of mycorrhizal colonization was associated with increased dry weights of shoots and roots, and shoot length and sheath diameter of onions seedlings regardless of the dominant $\mathrm{N}$ form supplied (except the root dry weight of $G$. intraradices at a $\mathrm{NH}_{4}^{+}: \mathrm{NO}_{3}^{-}$ratio of 1:3; Table 1). The higher shoot: root ratio of mycorrhizal plants compared with non-mycorrhizal controls indicates 
Table 4

Enzyme-produced pyruvate (EPY), total sulfur concentration (TSC), and organic sulfur concentration (OSC) in onion shoot

\begin{tabular}{|c|c|c|c|}
\hline $\begin{array}{l}\mathrm{N} \text { form ratio and } \\
\text { mycorrhizal status }\end{array}$ & $\begin{array}{c}\mathrm{EPY} \\
\left(\mu \mathrm{mol} \mathrm{ml}^{-1}\right)\end{array}$ & $\begin{array}{l}\mathrm{TSC} \\
(\%)\end{array}$ & $\begin{array}{l}\text { OSC } \\
(\%)\end{array}$ \\
\hline \multicolumn{4}{|l|}{$\mathrm{NH}_{4}^{+}: \mathrm{NO}_{3}^{-} 3: 1$} \\
\hline Non-mycorrhizal & 2.38 & 0.32 & 0.14 \\
\hline G. intraradices & 2.48 & 0.40 & 0.22 \\
\hline G. versiforme & 2.09 & 0.28 & 0.15 \\
\hline \multicolumn{4}{|l|}{$\mathrm{NH}_{4}^{+}: \mathrm{NO}_{3}^{-} 1: 1$} \\
\hline Non-mycorrhizal & 2.02 & 0.36 & 0.21 \\
\hline G. intraradices & 2.38 & 0.36 & 0.21 \\
\hline G. versiforme & 2.35 & 0.30 & 0.18 \\
\hline \multicolumn{4}{|l|}{$\mathrm{NH}_{4}^{+}: \mathrm{NO}_{3}^{-} 1: 3$} \\
\hline Non-mycorrhizal & 2.41 & 0.31 & 0.19 \\
\hline G. intraradices & 2.41 & 0.37 & 0.20 \\
\hline G. versiforme & 2.29 & 0.33 & 0.21 \\
\hline \multicolumn{4}{|l|}{ Significance $^{a}$ due to: } \\
\hline Inoculation treatment & NS & NS & NS \\
\hline $\mathrm{N}$ form ratio & NS & NS & NS \\
\hline Inoculation $\times \mathrm{N}$ form ratio & NS & NS & NS \\
\hline
\end{tabular}

${ }^{a}$ By analysis of variance; NS, not significant.

that mycorrhizal colonization contributed to the growth-promoting effect. Total yield increases for plants inoculated with $G$. versiforme were $31 \%, 117 \%$, and $190 \%$ with respect to the $\mathrm{NH}_{4}^{+}: \mathrm{NO}_{3}^{-}$ratios of $1: 3,1: 1$, and $3: 1$, and the corresponding values for $G$. intraradices inoculated plants were $0,96 \%$, and $46 \%$. Our results confirm that onion plants have a high mycorrhizal dependency at the early stages of growth, and that the enhanced plant growth varies with the fungal species and the $\mathrm{NH}_{4}^{+}: \mathrm{NO}_{3}^{-}$ratio in the substrate. Increased plant growth due to mycorrhizal colonization has been reported for wheat (Triticum aestivum L.) in association with $G$. mosseae when supplied with ammonium or nitrate (Hawkins and George, 2001), and for Erythrina poeppigiana (Cuenca and Azcón, 1994) in association with G. etunicatum, G. mosseae, and G. intraradices when supplied with nitrate (but not ammonium), but not for cucumber (Cucumis sativas L.) in association with $G$. mosseae regardless of whether $\mathrm{N}$ was supplied as nitrate or ammonium (Valentine et al., 2002).

Although onion plants are highly adapted to $\mathrm{NH}_{4}^{+}$as an $\mathrm{N}$ source (Abbès et al., 1995), this fact does not mean that $\mathrm{NH}_{4}^{+}$is the preferred form of $\mathrm{N}$ in terms of onion growth. As indicated in our experiment, the highest dry weights of nonmycorrhizal onion plants were observed at a $\mathrm{NH}_{4}^{+}: \mathrm{NO}_{3}^{-}$ratio of 1:3 (Table 1), implying that onion plants prefer $\mathrm{NO}_{3}^{-}$as the dominant $\mathrm{N}$ source. In fact, in 
practical horticulture, nitrate has been the more commonly used form of $\mathrm{N}$ in soilless vegetable-growing systems (Inal and Tarakcioglu, 2001). Gamiely et al. (1991) also found that onion growth was greater when $\mathrm{NO}_{3}^{-}$was present in the substrate compared with $\mathrm{NH}_{4}^{+}$as the sole $\mathrm{N}$ source. Mycorrhizal colonization shifts plant response to $\mathrm{N}$ species supplied from an $\mathrm{NH}_{4}^{+}: \mathrm{NO}_{3}^{-}$ratio of $1: 3$ in non-mycorrhizal plants to 3:1 for plants inoculated withy $G$. versiforme or 1:1 for plants inoculated with $G$. intraradices. Clearly, it may be possible to increase onion yields by selecting appropriate fungal species under natural conditions where environmental, seasonal, or spatially related variations in relation to different proportions of inorganic $\mathrm{N}$ ions occur (Marschner, 1995). Our result that plants inoculated with $G$. versiforme had the highest shoot and root dry weights at a $\mathrm{NH}_{4}^{+}: \mathrm{NO}_{3}^{-}$ratio of 3:1 is particularly interesting. A number of experimental studies have indicated that, compared with the $\mathrm{NO}_{3}^{-}$ion, $\mathrm{NH}_{4}^{+}$suppressed mycorrhizal colonization (Chambers et al., 1980; Hawkins and George, 2001; Valentine et al., 2002) and plant growth (Falkengren-Grerup, 1995). Although no significant differences in mycorrhizal colonization were found among the three $\mathrm{N}$ molar ratios, the colonization rate of $G$. versiforme was reduced when $\mathrm{NH}_{4}^{+}$was the dominant $\mathrm{N}$ form. Whether the extraradical hyphae of this fungus have a high glutamine synthetase activity, as reported by Breuninger et al. (2004) for G. intraradices, allowing uptake and assimilation of ammonium, needs to be investigated further.

Under the present experimental conditions, the nutrient solutions were irrigated periodically into the Perlite to sustain plant growth. The low adsorbing capacity of Perlite for $\mathrm{N}$ and $\mathrm{P}$ makes nutrients spatially available to the plant roots, and thus allows rapid nutrient uptake by mycorrhizal and non-mycorrizal plant roots. Therefore, the higher concentrations of $\mathrm{N}$ and $\mathrm{P}$ in mycorrhizal shoots (except in shoots of plants inoculated with $G$. versiforme at a $\mathrm{NH}_{4}^{+}: \mathrm{NO}_{3}^{-}$ ratio of 3:1 where the lower concentrations of $\mathrm{N}$ and $\mathrm{P}$ in mycorrhizal shoots were due to a concentration effect; Tables 2 and 3) may be ascribed partly to the physiological advantage of mycorrhizal colonization. In this respect, our results are partly in accordance with those of Cuenca and Azcon (1994) and Valentine et al. (2002). Apart from the possession of extensive extraradical mycelium by arbuscular mycorrhiza that permits the exploitation of less-mobile nutrients such as P (Smith and Read, 1997), $\mathrm{NH}_{4}^{+}$(Azcón et al., 1996), or $\mathrm{NO}_{3}^{-}$(Tobar et al., 1994) under drought conditions, mycorrhizal plants have been shown to be physiologically effective in taking up $\mathrm{P}$ (Tinker et al., 1992). Recent results suggest that AM fungi can increase the assimilation of $\mathrm{N}$ by the host plant (Azcón and Tobar, 1998), or the AM fungi may have nitrate reductase and/or glutamine synthetase activity per se (Azcón and Tobar, 1998; Breuninger et al., 2004).

Onion flavor intensity and quality are affected by a number of factors, including $\mathrm{SO}_{4}^{2-}$ availability, growth temperatures, levels of irrigation, and the amount and forms of N supplied (Randle and Lancaster, 2002). Pyruvic acid is a common decomposition product from all the flavor precursors, and is generally regarded as a broad indicator of gross flavor intensity in onions (Randle et al., 
1998). Neither mycorrhizal colonization nor N molar ratio significantly affected the concentration of pyruvic acid (EPY) in the bulbs, or TSC or OSC in the plant shoots (Table 4). These results are to some extent unexpected because the supply of N (Randle, 2000; Coolong et al., 2004) and S (Randle et al., 1999; Coolong et al., 2004) in the substrate has been shown to affect onion flavor, and much of the evidence now indicates that mycorrhizas can contribute to $\mathrm{N}$ uptake by plants (Johansen et al., 1996; Hawkins and George, 1999, 2001), as was also the case in our experiment. Early results of Rhodes and Gerdemann (1978) showed that mycorrhizas can take up S. The only paper investigating the effects of different forms of $\mathrm{N}$ on onion flavor showed that EPY and total $\mathrm{S}$ concentrations in mature onion bulbs were affected only when $\mathrm{NH}_{4}^{+}$was the sole $\mathrm{N}$ source (Gamiely et al., 1991). It is possible that under our experimental conditions mycorrhizamediated flavor effects were not yet fully developed because we harvested our plants at an early stage of growth when bulb formation was commencing. Nevertheless, as can be seen from Table 4, plants inoculated with $G$. intraradices often had higher bulb EPY, shoot TSC, and shoot OSC compared with nonmycorrhizal controls, and those inoculated with $G$. versiforme tended to have lower EPY, TSC, and OSC. As Randle (1992) pointed out, consumer perference can vary from very pungent to sweet, low-pungency onions. It is possible that the selection of an appropriate mycorrhizal fungus may be a useful approach in the production of onions of targeted flavor intensity and quality.

Our results indicate that mycorrhizal colonization contributes substantially to the growth and $\mathrm{N}$ and $\mathrm{P}$ uptake of onion plants, but not to bulb pungency at early stages of plant growth. The enhanced plant growth and nutrient uptake may have impacts on bulb pungency at later stages of growth when mature bulbs are formed. It is thus necessary to carry out longer-term experiments to further investigate the potential effects of mycorrhizal colonization on bulb pungency, in which more fungal taxa and Allium species could be investigated.

\section{ACKNOWLEDGMENTS}

This work was funded by the National Science Foundation of China [Projects 30200168 and GZ051-11(155)].

\section{REFERENCES}

Abbès, C., L. E. Parent, A. Karam, and D. Isfan. 1995. Effect of $\mathrm{NH}_{4}^{+} / \mathrm{NO}_{3}^{-}$ ratios on growth and nitrogen uptake by onions. Plant and Soil 171: 289296.

Amagase, H., B. L. Petesch, H. Matsuura, S. Kasuga, and Y. Itakura. 2001. Intake of garlic and its bioactive components. Journal of Nutrition 131 Supplement 3: 955S-962S. 
Azcón, R., M. Gomez, and R. Tobar. 1996. Physiological and nutritional responses by Lactuca sativa $\mathrm{L}$. to nitrogen sources and mycorrhizal fungi under drought conditions. Biology and Fertility of Soils 22: 156161.

Azcón, R., and R. M. Tobar. 1998. Activity of nitrate reductase and glutamine synthetase in shoot and root of mycorrhizal Allium cepa. Effect of drought stress. Plant Science 133: 1-8.

Breuninger, M., C. G. Trujillo, E. Serrano, R. Fischer, and N. Requena. 2004. Different nitrogen sources modulate activity but not expression of glutamine synthetase in arbuscular mycorrhizal fungi. Fungal Genetics and Biology 41: 542-552.

Chambers, C.A., S. E. Smith, and F. A. Smith. 1980. Effects of ammonium and nitrate ions on mycorrhizal infection, nodulation and growth of Trifolium subterraneum. New Phytologist 85: 47-62.

Charron, G., V. Furlan, M. Bernier-Cardou, and G. Doyon. 2001. Response of onion plants to arbuscular mycorrhizae. 2. Effects of nitrogen fertilization on biomass and bulb firmness. Mycorrhiza 11: 145-150.

Colwell, J. D. 1965. An automatic procedure for the determination of phosphorus in sodium ydrogen carbonate extracts of soil. Chemistry and Industry (London) 21: 893-895.

Coolong, T. W., D. A. Kopsell, D. E. Kopsell, and W. M. Randle. 2004. Nitrogen and sulfur influence nutrient usage and accumulation in onion. Journal of Plant Nutrition 27: 1667-1686.

Cuenca, G., and R. Azcón. 1994. Effects of ammonium and nitrate on the growth of vesicular-arbuscular mycorrhizal Erythrina poeppigiana O.I. Cook seedlings. Biology and Fertility of Soils 18: 249-254.

Falkengren-Grerup, U. 1995. Interspecies differences in the preference of ammonium and nitrate in vascular plants. Oecologia 102: 305-311.

Gaines, T. P., and G. A. Mitchell. 1979. Chemical methods for soil and plant analysis. University of Georgia Coastal Pain Experimental Station Agronomy Handbook 1: 59-64.

Gamiely, S., W. M. Randle, H. A. Mills, D. A. Smittle, and G. I. Banna. 1991. Onion plant growth, bulb quality, and water uptake following ammonium and nitrate nutrition. HortScience 26: 1061-1063.

Giovannetti, M., and B. Mosse. 1980. An evaluation of techniques for measuring vesicular arbuscular mycorrhizal infection in roots. New Phytologist 84: 489-500.

Hawkins, H. J., and E. George. 1999. Effect of plant nitrogen status on the contribution of arbuscular mycorrhizal hyphae to plant nitrogen uptake. Physiologia Plantarum 105: 694-700.

Hawkins, H. J., and E. George. 2001. Reduced ${ }^{15} \mathrm{~N}$-nitrogen transport through arbuscular mycorrhizal hyphae to Triticum aestivum L. supplied with ammonium vs. nitrate nutrition. Annals of Botany 87: 303311. 
Hendershot, W. H. 1985. An inexpensive block digester for nitrogen determination in soil samples. Communications in Soil Science and Plant Analysis 16: $1271-1278$.

Inal, A., and C. Tarakcioglu. 2001. Effects of nitrogen forms on growth, nitrate accumulation, membrane permeability, and nitrogen use efficiency of hydroponically grown bunch onion under boron deficiency and toxicity. Journal of Plant Nutrition 24: 1521-1534.

Johansen, A., R. D. Finlay, and P. A. Olsson. 1996. Nitrogen metabolism of external hyphae of the arbuscular mycorrhizal fungus Glomus intraradices. New Phytologist 133: 705-712.

Kapoor, R., G. Bhoopander, and K. G. Mukerji. 2004. Improved growth and essential oil yield and quality in Foeniculum vulgare Mill on mycorrhizal inoculation supplemented with $\mathrm{P}$ fertilizer. Bioresource Technology 93: 307-311.

Marschner, H. 1995. Mineral nutrition of higher plants. London: Academic Press.

Randle, W. M. 1992. Onion germplasm interacts with sulfur fertility for plant sulfur utilization and bulb pungency. Euphytica 59: 151-156.

Randle, W. M. 2000. Increasing nitrogen concentration in hydroponic solutions affects onion flavor and bulb quality. Journal of the American Society for Horticultural Science 125: 254-259.

Randle, W. M., D. A. Kopsell, D. E. Kopsell, R. L. Snyder, and R. Torrance. 1998. Field sampling short-day onions for bulb pungency. HortTechnology 8: 329-332.

Randle, W. M., D. E. Kopsell, D. A. Kopsell, and R. L. Snyder. 1999. Total sulfur and sulfate accumulation in onion is affected by sulfur fertility. Journal of Plant Nutrition 22: 45-51.

Randle, W. M., and J. E. Lancaster. 2002. Sulphur compounds in alliums in relation to flavour quality. In Allium crop science: Recent advances, eds. H. Rabinowitch and L. Currah, 329-356. Wallingford, U.K.: CAB International.

Randle, W. M., J. E. Lancaster, M. L. Shaw, K. H. Sutton, R. L. Hay, and M. L. Bussard. 1995. Quantifying onion flavor compounds responding to sulfur fertility - sulfur increases levels of alk(en)yl cysteine sulfoxides and biosynthetic intermediates. Journal of the American Society for Horticultural Science 120: 1075-1081.

Rhodes, L. H., and J. W. Gerdemann. 1978. Hyphal translocation and uptake of sulfur by vesicular-arbuscular mycorrhizae of onion. Soil Biology and Biochemistry 10: 361-364.

Smith, S. E., and D. J. Read. 1997. Mycorrhizal Symbiosis, 2nd edition; London: Academic Press.

Tinker, P. B., M. D. Jones, and D. M. Durall. 1992. A functional comparison of ecto- and endomycorrhizals. In Mycorrhizas in ecosystems, eds. D. J. 
Read, D. H. Lewis, A. H. Fitter, and I. J. Alexander, 303-310. Wallingford, $\mathrm{UK}$ : CAB International.

Tobar, R., R. Azcón, and J. M. Barea. 1994. Improved nitrogen uptake and transport from ${ }^{15} \mathrm{~N}$-labeled nitrate by external hyphae of arbuscular mycorrhiza under water-stressed conditions. New Phytologist 126: 119-122.

Valentine, A. J., B. A. Osborne, and D. T. Mitchell. 2002. Form of inorganic nitrogen influences mycorrhizal colonization and photosynthesis of cucumber. Scientia Horticulturae 92: 229-239. 